Int. J. Electrochem. Sci., 11 (2016) 3908 - 3920

\title{
Effect of Short Term Aging on Microstructure Evolution, Pitting and Intergranular Corrosion Behaviour of UNS31254
}

\author{
Yipeng Liu ${ }^{1}$, Ning Zhong ${ }^{2}$, YangTing Sun ${ }^{1}$, Yiming Jiang ${ }^{1, *}$ \\ ${ }^{1}$ Department of Materials Science of Fudan University, Shanghai, PR China \\ ${ }^{2}$ Institute of Marine Materials Science and Engineering of Shanghai Maritime University, Shanghai, \\ PR China \\ *E-mail: ymjiang@fudan.edu.cn
}

doi: $10.20964 / 110496$

Received: 24 February 2016 / Accepted: 19 March 2016 / Published: 1 April 2016

\begin{abstract}
Here the intergranular and pitting corrosion resistance of super austenitic stainless steel Type UNS31254 was investigated, whose performance declined obviously after aging at $900{ }^{\circ} \mathrm{C}$ for short terms. Test methods including the nitric acid immersion test and the potentiostatic pulse technique (PPT) were applied respectively, and the results showed that the samples were highly sensitive to those two types of localized corrosion after aging within 180 minutes. Then the segregation between the interior and boundaries of grains eased while the general corrosion became dominated. The transmission electron microscope (TEM) further revealed molybdenum-rich Laves-related phases formed along the boundaries for only 10 minutes and they were the main culprit for the degradation. Finally, to offer guidance for the process of UNS31254, the welding joints were also checked and the evaluation method of pitting corrosion was discussed.
\end{abstract}

Keywords: Super Austenitic Stainless steel; Pitting corrosion; Precipitation; Potentiostatic Pulse Technique

\section{$\underline{\text { FULL TEXT }}$}

(C) 2016 The Authors. Published by ESG (www.electrochemsci.org). This article is an open access article distributed under the terms and conditions of the Creative Commons Attribution license (http://creativecommons.org/licenses/by/4.0/). 